\title{
ESTIMATING THE WILLINGNESS TO PAY FOR DARK SKIES
}

\author{
David M. Mitchell ${ }^{1}$, Terrel Gallaway ${ }^{2}$, Reed Olsen ${ }^{3}$ \\ ${ }^{1}$ Professor, Economics Department, Missouri State University, Missouri, USA \\ ${ }^{2}$ Professor, Economics Department, Missouri State University, Missouri, USA \\ ${ }^{3}$ Professor, Economics Department, Missouri State University, Missouri, USA
}

\begin{abstract}
This work investigates the monetary value that people assign towards reducing light pollution in their hometown and in US national parks. Light pollution commonly refers to excessive or obtrusive artificial light caused by bad lighting design. Light pollution generates significant costs including negative impacts on wildlife, human health, astronomy, and wasted energy. The current work uses a contingent valuation method to determine the amount of damages that the public experiences from light pollution. The data is from surveys administered in four US national parks. We find that the more exposure and familiarity people have with light pollution, the more they are willing to pay to moderate it. Furthermore, approximately 50 percent of people surveyed were willing to pay some positive amount to reduce light pollution.
\end{abstract}

Keywords: light pollution, contingent valuation, national parks, artificial light, lighting design - ***.

\section{INTRODUCTION}

Although light pollution has been a recognized problem in the natural sciences for some time, it has recently become a concern among economists as well. Quite simply, light pollution is the presence of obtrusive artificial light that disturbs both humans and animals. Light pollution can be as isolated as a homeowner suffering disturbed sleep because of street lights shining into their bedroom at night or as widespread as the 'glow' of a city at night that can be seen from up to 50 or even 100 miles away.

Light pollution is well known to be a serious problem in the fields of professional and amateur astronomy as the presence of light pollution impedes the astronomer's ability to see stars and other celestial objects. Furthermore, light pollution damages the scenic night skies in many national and state parks and other areas that are noted for the beauty of their night skies.Take for example Chaco Culture National Historical Park which has listed dark night skies as one of the assets it attempts to preserve for the public. Despite its efforts and location in a remote part of New Mexico, Chaco Canyon is under increasing threat from light pollution. Its ability to preserve pristine dark skies is in jeopardy. This serves to diminish the quality of amenities that these areas have which reduces a visitor's willingness to pay to visit the area. To give the reader a sense of how pervasive the problem of light pollution is, consider that currently 66 percent of the United States and 50 percent of the European population can no longer see the Milky Way at night [1]. Moreover, approximately 40 percent of the United States and almost 20 percent of the European Union population has lost the ability to view the night sky with an eye that can adapt to the darkness of the night sky-in other words, it is as if they never experience 'nighttime' [2].

However, the problems of light pollution do not stop with aesthetic issues. Research has shown that light pollution disrupts the migration patterns of nocturnal birds and causes hatchling sea turtles to become confused and therefore unable to make it to the sea before being eaten by predators $[3,4,5]$. Furthermore, light pollution may be linked to an increased risk of breast cancer in women due to the lower levels of melatonin that the body produces when it is exposed to light pollution which, ostensibly, keeps people from falling into a deep sleep [6, 7].

Furthermore, since energy is required to produce artificial lighting, the existence of light pollution helps to contribute to increased carbon dioxide emissions and global warming. In the United States, 25 percent of the 4,054 million megawatt hours (mwh) of electricity produced is used for lighting and approximately $30 \%$ of this generated light is 'wasted' as light pollution or light trespass. This translates into 304 million mwh of electricity needlessly being generated at a cost of $\$ 28.7$ billion a year. Additionally, this unnecessary electricity usage generated an additional 275 million metric tons of $\mathrm{CO} 2[8,9]$. Eliminating light pollution would be the $\mathrm{CO} 2$ equivalent of removing almost 41 million cars off of the road $[10,11]$.

In these aforementioned ways, light pollution is similar in nature to many other forms of 'traditional' pollutants (such as air, water, noise, hazardous waste, and excess CO2) that economists have studied and quantified the pollutant's level of damages [12 - 16]. We build upon the work of recent literature that has studied light pollution $[17-21]$ and we endeavor, via the Contingent Valuation Method (CVM), to determine how much people are willing to pay for dark skies. Our results indicate that approximately half of people surveyed were willing to pay some positive amount to mitigate light pollution. We divide this paper up into the following sections: a brief review of the literature concerning methods to determine willingness to pay for non-market goods, followed by a discussion of our methodology. We then finish up with some results and conclusions as well as areas of future research. 


\section{METHODOLOGIES USED TO MEASRUE} THE VALUATION OF NON-MARKET GOODS

One of the fundamental issues in light pollution research is to determine how much people are willing to pay to reduce light pollution. We build upon the work of Gallaway, Olsen, and Mitchell $[17 ; 18]$ who examined the relationship between social and economic conditions as they were related to light pollution.

There are many different methodologies that have been devised to attempt to measure a person's willingness to pay for a quantity of a non-market good. Of course, with goods that are actively traded in a market, e.g. cars, these methods are not needed as consumers have a history of buying/selling the good and therefore placing values on it. However, people have a difficult time placing a value on goods that are thinly traded, or not traded at all, so that the usual forms of valuation must be modified to account for the purchaser's lack of experience in 'buying' this good.

One of the most popular of these methods is contingent valuation $(\mathrm{CVM})$ where buyers are asked to place a value on the quantity of an inactive or thinly traded good. This is usually accomplished via a survey where respondents are asked classifying questions such as age, sex, income, employment status, etc. The valuation questions for the good under study can take many forms: open-ended, iterative bidding, and dichotomous choice. Under the openended scenario, people are asked to reveal their maximum willingness to pay. It should be noted that no values are suggested to them. In iterative bidding, a series of fixed and predetermined dollar amounts are given to the respondent until they reveal their maximum willingness to pay. In the final method, people are simply asked if they would be willing to pay $\$ \mathrm{X}$ for some good or activity.

CVM studies have been used to place value estimates on many types of goods. Shultz et. al. [22] discovered that people were WTP $\$ 2.45$ per visitor per day to prevent development of the Jemez Mountains in New Mexico which form the southernmost tip of the Rocky Mountains. Sorg and Loomis [23] studied the amenity value of forests and discovered a range from almost $\$ 13$ per day per visitor to hike in Colorado to $\$ 74$ per day to backpack in Oregon. Finally, Gallaway, Olsen, and Mitchell [17] estimated the aggregate value that visitors place on the night skies at Great Basin National Park at close to $\$ 1,000,000$ per year.

A second popular method is the travel cost method. The travel cost method estimates the costs incurred to visit a destination. For example, consider a family that will incur travel costs of $\$ 1,000$ in food, gas, and hotel rooms for a weeklong visit to the Grand Canyon. In addition, the family will lose $\$ 1,500$ in wages during the week. If the family is willing to undertake the trip, then they value the Grand Canyon by at least $\$ 2,500$. If however, the family is not willing to take the trip, then the value that they place on the Grand Canyon is less than $\$ 2,500$. The travel cost method has been used to estimate the value of many goods including, for example, the benefits of altering water flows in the Ticino River in Switzerland for fisherman. Estimates indicated that people valued the altered flows at 440 Swiss Francs for a total economic value of 1.3 million Swiss Francs [24].

Both of these methods have been used separately and in conjunction to determine the value of these non-market goods. For example, Herath, Gamini and Kennedy [25] used both contingent valuation methods and the travel cost method to estimate the value of Buffalo National Park in Australia. They determined that the consumer surplus estimates from the travel cost method were higher than those obtained from contingent valuation methods. However, in another study, Clarke [26] found that the contingent valuation method produced results that were almost twice as large as those from the travel cost method. Clarke was examining the economic value of improving access to mammographic screening in rural Australia.

\section{CV METHODOLOGY AND RESULTS}

We conducted a survey to determine people's willingness to pay to preserve dark skies at 4 different US national parks in the summers of 2007 and 2008. These parks were Yellowstone, Great Basin, Mesa Verde, and Chaco Canyon. We employed different techniques to keep the survey methods random. For example, at Mesa Verde, every third person to pass a certain point on a trailhead was asked if they would be willing to take a survey. We received a total of 858 responses on 5 different versions of the survey.There were actually 6 different versions with version 1 being a 'master copy' of all of the different version questions. However, we did not employ version 1 in the interview process. To maintain consistency, we will refer to versions 2 through 6 throughout this and subsequent papers. Table 1 has a list of the number of surveys, response rate, and other selected characteristics for each of the parks. We had an average response rate of $55 \%$, with respondents having an average income of $\$ 89,142$. Approximately $46 \%$ indicated that the night sky in the park was an important or very important component of their travel plans and subsequently $20 \%$ of the people surveyed brought some form of equipment for observing the night sky. This would include binoculars, telescopes, and cameras.

Since some people might not even be aware of light pollution, we asked people if they had seen the night sky in this park. The reasoning behind this question is an important one. If someone who has lived with light pollution their whole lives was to come to the park and take the survey before they had seen the night sky, it might bias downward their valuation responses. This is especially true for those who have not noticed sky glow because they do not know anything different. Approximately $3.5 \%$ of the sample population both lived in an urban or suburban area but had never noticed skyglow at their place of residenceostensibly because they were not aware of it or do not care. Approximately half of our respondents though indicated that they were unable to see the Milky Way from their homes and that $68 \%$ were bothered by this fact. Therefore, it is not 
surprising that $50 \%$ of our respondents indicated that they would be willing to pay some positive dollar amount to preserve dark skies, either at home or at the national park they were visiting.

Table -1: Summary of Selected Survey Characteristics

\begin{tabular}{|l|l|l|l|l|}
\hline & $\begin{array}{l}\text { Yellow } \\
\text {-stone }\end{array}$ & $\begin{array}{l}\text { Great } \\
\text { Basin }\end{array}$ & $\begin{array}{l}\text { Mesa } \\
\text { Verde }\end{array}$ & $\begin{array}{l}\text { Chaco } \\
\text { Canyon }\end{array}$ \\
\hline $\begin{array}{l}\text { Number of } \\
\text { Surveys }\end{array}$ & 298 & 138 & 173 & 249 \\
\hline $\begin{array}{l}\text { Response } \\
\text { Rate }\end{array}$ & $46 \%$ & $84 \%$ & $51 \%$ & $77 \%$ \\
\hline $\begin{array}{l}\text { Average } \\
\text { Income }\end{array}$ & 94,441 & 84,783 & 86,855 & 81,849 \\
\hline $\begin{array}{l}\text { Night Sky in } \\
\text { Travel Plans }\end{array}$ & $51 \%$ & $47 \%$ & $38 \%$ & $37 \%$ \\
\hline $\begin{array}{l}\text { Seen Night } \\
\text { sky in Park }\end{array}$ & $59 \%$ & $42 \%$ & $46 \%$ & $30 \%$ \\
\hline $\begin{array}{l}\text { Brought } \\
\text { Equipment }\end{array}$ & $24 \%$ & $19 \%$ & $12 \%$ & $14 \%$ \\
\hline $\begin{array}{l}\text { WTP a } \\
\text { positive } \\
\text { amount }\end{array}$ & $47 \%$ & $52 \%$ & $52 \%$ & $61 \%$ \\
\hline $\begin{array}{l}\text { Live in rural } \\
\text { area }\end{array}$ & $31 \%$ & $26 \%$ & $31 \%$ & $22 \%$ \\
\hline $\begin{array}{l}\text { Can't see } \\
\text { Milky Way }\end{array}$ & $39 \%$ & $51 \%$ & $51 \%$ & $50 \%$ \\
\hline $\begin{array}{l}\text { Notice Sky } \\
\text { Glow }\end{array}$ & $85 \%$ & $87 \%$ & $84 \%$ & $94 \%$ \\
\hline $\begin{array}{l}\text { Bothered by } \\
\text { Sky Glow }\end{array}$ & $68 \%$ & $63 \%$ & $62 \%$ & $81 \%$ \\
\hline
\end{tabular}

Even though knowing that people are WTP something to preserve dark skies is important, finding out how much they are WTP is of greater interest. To determine this, we utilized 5 different versions of the survey that were identical in every respect except the valuation questions. A list of the question specifics is in Table 2 with the general questions listed below (the portion in italics is the portion that was changed depending upon the version number). We included different questions to test for consistency between the data. For example, if people were willing to pay a positive dollar amount to double the number of stars at home, would they also be willing to pay more, however slightly, to triple the number of stars at home? Of course, it is possible that they would not be willing to pay as much to triple the number of stars at home due to diminishing marginal valuation-but if they valued dark skies, then we would expect them to pay a positive amount to preserve the dark skies in the park.

Table 3 contains the most relevant descriptive statistics for our analysis up to this point, most of which are dummy variables that correspond to specific questions asked on the surveys. The variables Version2 through Version6 are dummy variables that refer to the different versions of the survey while Version56 is a dummy variable which tries to test whether people were more or less likely to pay to preserve dark skies if the survey had two questions rather than one. Year is a dummy variable set equal to 1 for surveys conducted during 2007 and set equal to 0 for surveys conducted in 2008. Week 1 is equal to 1 if people are staying in the national park at least one week and income is the person's self reported income in dollars.

Milky combines two questions on the survey. If people indicated either that the Milky Way was not visible or that only a few stars are visible from their hometown, then Milky was assigned a value of 0 . If the Milky Way was obvious or could at least be barely seen, then its value was one. A similar measure of what type of night sky people can see is included in the Rural variable which is equal to 1 if people self-identified themselves as living in rural areas. We had further measures of people's perception of light pollution with Glow1 and Glow2. Glow1 asked people if they had noticed 'sky glow', i.e. light pollution, in their hometown while Glow2 asked them if they were bothered by 'skyglow' in their hometown. If people answered yes to either question, they were assigned a value of 1 and 0 otherwise.

Table -2: List of Valuation Questions Asked of Survey Respondents

\begin{tabular}{|l|l|}
\hline Version 2 & $\begin{array}{l}\text { Federal Income Taxes per year to } \\
\text { preserve dark skies -National Park }\end{array}$ \\
\hline Version 3 & $\begin{array}{l}\text { Utility Bill per month to double visible } \\
\text { stars -Hometown }\end{array}$ \\
\hline Version 4 & $\begin{array}{l}\text { Utility Bill per month to triple visible } \\
\text { stars -Hometown }\end{array}$ \\
\hline Version 5 & $\begin{array}{l}\text { Federal Income Taxes per year to } \\
\text { preserve dark skies -National Park and } \\
\text { Utility Bill per month to double visible } \\
\text { stars -Hometown }\end{array}$ \\
\hline Version 6 & $\begin{array}{l}\text { Federal Income Taxes per year to } \\
\text { preserve dark skies -National Park and } \\
\text { Utility Bill per month to triple visible } \\
\text { stars -Hometown }\end{array}$ \\
\hline
\end{tabular}

Text of Sample Question

On a clear night, the sky in this park is typically very dark, full of stars, and the Milky Way is obvious. In more populated areas, night skies are brighter and fewer stars are visible. Compare the dark skies in this park to the night sky observable on a clear night from your home. Imagine the night sky here was about to become as bright as the night sky there. If you were certain that higher federal income taxes would all go towards successfully preserving the dark skies in this park, given the sacrifice taxes entail, what is the most your household would be willing to pay each year to preserve the dark sky in this park? \$

Nothing, the night sky above my home is virtually free from sky glow

Text of Sample Question

In populated areas, the glow from electric lights can create a "sky glow" which reduces the number of visible stars. Alternative lighting design can reduce much of this sky glow without compromising the desired effects of lighting. If you could be certain that 
alternative lighting would reduce sky glow in your hometown enough to double the number of stars visible on a clear night, what is the most your household would be willing to pay, on your monthly utility bill, to reduce sky glow? $\$$

Nothing, the night sky above my home is virtually free from sky glow

We also asked people detailed questions about what equipment, if any, they brought with them to observe the night sky. We combined these questions into one dummy variable, Equip, which is equal to 1 if they brought equipment with them and 0 if they did not.

Other questions were designed to elicit people's feelings and activities about being able to see a dark sky at night. A set of 6 questions was asked that allowed us to determine survey respondent's familiarity with amateur astronomy. These sets of questions asked people to rank their astronomical activities such as noticing the phases of the moon, watching meteor showers, and stargazing with family, etc. The ranking was on a 5 point Likert scale with 1 being never, 2 equaling rarely, 3 equaling sometimes, 4 being often, and 5 being very often. The rankings for these activities were averaged. If this average was greater than 4 , the dummy variable Astronomy which was set equal to 1 . If the average Likert ranking for astronomical activity was less than 4, then Astronomy was set equal to 0 . A similar methodology was used to gauge people's rankings of their personal benefits from being able to see the night sky. On the same 5 point Likert scale with 1 being never and 5 being very often, people ranked the perceived benefits/emotional connections they make when seeing lots of stars at night. For example, people were asked to rank how important making a spiritual connection, inspiring creativity, connecting with nature, connecting with the past, etc. was to them personally. A dummy variable for connecting with nature was created, Nature, and set equal to 1 if people responded that it was important or very important to them when looking at the night sky.

We also combined some of the measures of age into one variable. We had seven different categories of age from 18 to $75+$ on the surveys. Initial analysis indicated that those over age 65 acted in a similar manner. Therefore, we created Age which is equal to one if someone is over age 65 and zero if they are less than 65 .

Our quantitative analysis is based on trying to answer two different questions. The first question is "Are people willing to pay something to preserve night skies"? In order to answer this question, we created a dummy variable WTP which took a value of 0 if people indicated on the survey that they were not willing to pay anything to preserve dark skies, either at home or in the park. Therefore, those who indicated that they were willing to pay something, no matter how small, were assigned a value of 1 . We have used the WTP variable in a series of logit models to determine what characteristics will alter the probability of people paying something to preserve dark skies. These results are listed in Table 4. Although we do not need a separate dummy variable for each survey version, we do need a dummy variable for versions 5 and 6 which both contained 2 questions on valuation rather than one question on valuation. Logistic regression runs states that people exposed to 2 questions were $8 \%$ to $10 \%$ more likely to state that they were willing to pay a positive amount than those exposed to one question.

Table -3: Summary of Selected Survey Characteristics

\begin{tabular}{|l|l|l|l|l|l|}
\hline Variable & Obs & Mean & $\begin{array}{l}\text { Std. } \\
\text { Dev. }\end{array}$ & Min & Max \\
\hline Version2 & 858 & 0.33 & 0.47 & 0 & 1 \\
\hline Version3 & 858 & 0.17 & 0.37 & 0 & 1 \\
\hline Version4 & 858 & 0.17 & 0.37 & 0 & 1 \\
\hline Version5 & 858 & 0.17 & 0.37 & 0 & 1 \\
\hline Version6 & 858 & 0.17 & 0.37 & 0 & 1 \\
\hline Version56 & 858 & 0.33 & 0.47 & 0 & 1 \\
\hline Year & 858 & 0.74 & 0.44 & 0 & 1 \\
\hline Week1 & 858 & 0.07 & 0.26 & 0 & 1 \\
\hline Milky & 858 & 0.53 & 0.50 & 0 & 1 \\
\hline Age & 858 & 0.08 & 0.27 & 0 & 1 \\
\hline Astronomy & 858 & 0.18 & 0.38 & 0 & 1 \\
\hline Nature & 858 & 0.72 & 0.45 & 0 & 1 \\
\hline Income & 663 & 88,723 & 59,923 & 0 & 500,000 \\
\hline Equip & 852 & 0.20 & 0.40 & 0 & 1 \\
\hline Rural & 858 & 0.29 & 0.45 & 0 & 1 \\
\hline Glow1 & 842 & 0.90 & 0.29 & 0 & 1 \\
\hline Glow2 & 838 & 0.71 & 0.45 & 0 & 1 \\
\hline WTP & 858 & 0.52 & 0.49 & 0 & 1 \\
\hline WTPPPARK & 858 & 29.42 & 108.26 & 0 & 2,000 \\
\hline
\end{tabular}

Examining the rest of the Table 4 exposes some interesting concepts in understanding peoples' willingness to pay to reduce light pollution. The reader will notice that in every regression, Age is negative and statistically significant indicating that people over the age of 65 are not as willing to pay to preserve dark skies by 13 to $22 \%$ depending upon the model chosen. This can be explained through a variety of channels. Perhaps they are more cognizant of the fact that they have limited income since they are either in or approaching retirement and are therefore less willing to part with their money. Alternatively, they could view light as a strong deterrent to crime and are therefore do not want to increase their risk of becoming a victim of crime by reducing light pollution. 
The more people were exposed to light pollution, the more probability there was that they would be willing to pay something to reduce it. Examination of the Milky, Glow1, and Glow2 variables states that there is generally a statistically significant relationship between people's perceptions of light pollution and their willingness to pay to reduce it. If people notice light pollution and are bothered by it, they are $18 \%$ to $20 \%$ more likely to be willing to pay something to reduce it while those who can see the Milky Way from their house are about $11 \%$ less likely to pay to reduce light pollution. Similarly, those in rural areas were less willing to pay to reduce light pollution by 12 to $23 \%$. The answer to this is fairly intuitive. Ceteris paribus, people in rural areas will be less exposed to light pollution and are more likely to be able to see a fairly dark sky at night. Since they already have this 'good', it does not make sense that they would be willing to pay more to preserve dark skies in another part of the country.

The last two dummy variables are Nature and Equip which are both positive and significant. People are about 10 to $11 \%$ more likely to be willing to pay something to reduce light pollution if they brought equipment with them to view the sky while those who make a connection with nature via dark skies are 21 to $24 \%$ more likely. This should not be surprising since people who feel these 'personal' connections are undoubtedly receiving utility from this experience. It is surprising though that people who are bringing equipment specifically to look at the night sky are not willing to pay more to preserve the night sky in the national park. It is possible that there is some selection bias at work here. Perhaps, those who have equipment to view the night sky presumably live in an area where they are able to practice their hobby on a relatively frequent basis. If they live in an area that is heavily polluted with sky glow, perhaps they don't purchase the equipment in the first place to view the stars. Finally, interestingly enough, income is not significant in the regressions.

The second empirical questions we sought to answer was, "If people are willing to pay more to preserve dark skies, how much are they willing to pay"? Here we regressed, using OLS, some different variables onto the dollar amounts people indicated that they would be willing to pay to preserve dark skies in the national park. Therefore, this variable, WTPPARK, is from answers received from versions 2, 5, and 6 and relate to the amount for the parks only. Table 5 shows these estimates. Once again, it is necessary to include a dummy variable for versions 5 and 6 since, ceteris paribus, people who answered one of these surveys were willing to pay approximately 35 to 40 more dollars than those who just answered survey versions with one question only. This value falls though as the regression becomes less parsimonious. Also, once again, the coefficient estimate for Age is negative in all regressions, although this time it is not statistically significant.
Table -4: Logit Models for WTP A Positive Amount to Reduce Light Pollution

\begin{tabular}{|c|c|c|c|}
\hline & Model 1 & Model 2 & Model 3 \\
\hline Constant & $\begin{array}{l}0.729 * * * \\
(0.19)\end{array}$ & $\begin{array}{l}-1.65 * * * \\
(0.35)\end{array}$ & $\begin{array}{l}-1.337 * * * \\
(0.42)\end{array}$ \\
\hline Version56 & $\begin{array}{l}0.361 * * \\
(.18)\end{array}$ & $\begin{array}{l}0.31^{*} \\
(0.16)\end{array}$ & $\begin{array}{l}0.385^{*} \\
(0.19)\end{array}$ \\
\hline Age & $\begin{array}{l}-0.885 * * * \\
(.32)\end{array}$ & $\begin{array}{l}-0.973 * * * \\
(0.30)\end{array}$ & $\begin{array}{l}-0.773 * * \\
(0.34)\end{array}$ \\
\hline Milky & $\begin{array}{l}-0.43 * * \\
(0.19)\end{array}$ & $\begin{array}{l}-0.369 * * \\
(0.18)\end{array}$ & $\begin{array}{l}-0.487 * * \\
(0.24)\end{array}$ \\
\hline Week1 & $\begin{array}{l}0.658^{*} \\
(.36)\end{array}$ & $\begin{array}{l}0.357 \\
(0.30)\end{array}$ & $\begin{array}{l}0.408 \\
(0.37)\end{array}$ \\
\hline Income & $\begin{array}{l}-2.69 \text { E-07 } \\
(1.46 \quad \text { E- } \\
06)\end{array}$ & & $\begin{array}{l}1.14 \mathrm{E}-06 \\
(1.58 \quad \text { E- } \\
06)\end{array}$ \\
\hline Rural & $\begin{array}{l}-0.963 * * * \\
(0.21)\end{array}$ & $\begin{array}{l}-0.661 * * * \\
(0.20)\end{array}$ & $\begin{array}{l}-0.568^{* *} \\
(0.23)\end{array}$ \\
\hline Equip & & $\begin{array}{l}0.444 * * \\
(0.19)\end{array}$ & $\begin{array}{l}0.419 * \\
(0.23)\end{array}$ \\
\hline Nature & & $\begin{array}{l}1.00 * * * \\
(0.18)\end{array}$ & $\begin{array}{l}0.872 \text { *** } \\
(0.22)\end{array}$ \\
\hline Glow1 & & $\begin{array}{l}0.750 * * \\
(0.34)\end{array}$ & $\begin{array}{l}0.721 * * \\
(0.40)\end{array}$ \\
\hline Glow2 & & $\begin{array}{l}0.849 * * * \\
(0.20)\end{array}$ & $\begin{array}{l}0.754 * * * \\
(0.23)\end{array}$ \\
\hline Astronomy & $\begin{array}{l}0.469 * * \\
(0.22)\end{array}$ & & \\
\hline Obs & 663 & 835 & 655 \\
\hline Pseudo R2 & 7.4 & 15.2 & 13.3 \\
\hline
\end{tabular}

Surprisingly, for different regression iterations, only Version, Milky, and Equip are statistically significant-and of the predicted sign. Those who can see the Milky Way at night are less willing to pay for dark skies in the national park by between $\$ 16$ to $\$ 18$. Similarly, those who have brought equipment to view the night sky are willing to pay roughly the same amount to see a dark night sky in the national park. It should be remembered that people who brought equipment had a higher probability of being willing to pay something to preserve dark skies in the park, but that this probability was roughly half the size of those who made a connection with nature, noticed sky glow, or were bothered by sky glow. The fact that they are now the only group whose higher contribution to preserve dark skies is significant and warrants further investigation.

Table -5: WTP to Reduce LP in thePark

\begin{tabular}{|l|l|l|l|l|}
\hline & Model 4 & Model 5 & Model 6 & Model 7 \\
\hline Constant & $29.43 * * *$ & $34.06 * *$ & $34.00 * * *$ & 5.37 \\
& $(6.11)$ & $(13.32)$ & $(10.38)$ & $(15.19)$ \\
\hline Version56 & $35.79 * * *$ & $35.80 * * *$ & $39.62 * * *$ & $36.04 * * *$ \\
& $(7.72)$ & $(7.70)$ & $(9.69)$ & $(7.89)$ \\
\hline Age & -16.49 & -17.05 & -15.58 & -14.73 \\
& $(13.16)$ & $(13.16)$ & $(17.83)$ & $(13.73)$ \\
\hline
\end{tabular}




\begin{tabular}{|c|c|c|c|c|}
\hline Milky & $\begin{array}{l}-17.88^{* *} \\
(7.32)\end{array}$ & $\begin{array}{l}-17.54 * * \\
(7.26)\end{array}$ & $\begin{array}{l}-18.95^{*} \\
10.62)\end{array}$ & $\begin{array}{l}-15.80^{*} \\
(8.64)\end{array}$ \\
\hline Week1 & & & $\begin{array}{l}-2.81 \\
(18.32)\end{array}$ & $\begin{array}{l}-8.76 \\
(14.27)\end{array}$ \\
\hline Income & & & $\begin{array}{ll}-3.07 & \text { E- } \\
06 & \\
(8.02 & E- \\
05) & \end{array}$ & \\
\hline Rural & & & $\begin{array}{l}-6.16 \\
(11.95) \\
\end{array}$ & $\begin{array}{l}0.28 \\
(9.82) \\
\end{array}$ \\
\hline Equip & & & & $\begin{array}{l}17.37 * \\
(9.46)\end{array}$ \\
\hline Nature & & & & $\begin{array}{l}1.97 \\
(8.55) \\
\end{array}$ \\
\hline Glow1 & & & & $\begin{array}{l}3.46 \\
(14.52) \\
\end{array}$ \\
\hline Glow2 & & & & $\begin{array}{l}20.72 \\
(9.87) \\
\end{array}$ \\
\hline Astronomy & $\begin{array}{l}-5.62 \\
(9.57) \\
\end{array}$ & & & \\
\hline $\begin{array}{l}\text { Great } \\
\text { Basin }\end{array}$ & & $\begin{array}{l}21.93 * * \\
(10.99)\end{array}$ & & \\
\hline Chaco & & $\begin{array}{l}5.88 \\
(11.35) \\
\end{array}$ & & \\
\hline MesaVerde & & $\begin{array}{l}-9.90 \\
(10.78)\end{array}$ & & \\
\hline Year2007 & & $\begin{array}{l}-10.25 \\
(10.39) \\
\end{array}$ & & \\
\hline Obs & 858 & 858 & 858 & 858 \\
\hline $\mathrm{R}^{2}$ & 3.5 & 4.3 & 4.4 & 5.0 \\
\hline
\end{tabular}

\section{CONCLUSION}

This paper is an extension of earlier work investigating the economics of a negative externality called light pollution. Surveys were administered at four different national parks during the summer of 2007 and 2008 to gage peoples' willingness to pay to preserve dark skies. Initial analysis from this CV study indicates that approximately $50 \%$ of the visitors to the national parks were willing to pay something to preserve dark skies. However, peoples' lack of experience and unfamiliarity in buying a non-market good such as dark skies leads them to be unable to place a specific dollar value on exactly how much utility they actually receive from dark skies. Further areas of future research are to employ the travel cost method to investigate this valuation phenomenon in a different light. Also, we intend to use a GIS framework using census data, zip codes, and light pollution data at a census level to determine how much light pollution people actually face. This will help us determine how much knowledge people have about this externality.

\section{REFERENCES}

[1]. Cinzano, P., F. Falchi and C.D. Elvidge. 2001. "The First World Atlas of the Artificial Night Sky Brightness." Monthly Notices of the Royal Astronomical Society, 328, 689-707.
[2]. Cinzano, P., F. Falchi and C.D. Elvidge. 2001. "Naked Eye Star Visibility and Limiting Magnitude Mapped from DMSP-OLS Satellite Data." Monthly Notices of the Royal Astronomical Society, 323, 34-46.

[3]. Verheijen, F.J. 1985, Photopollution: artificial light optic spatial control systems fail to Cope with Incidents, causations, remedies, Experimental Biology., 44, 1-18

[4]. Salmon, M., M. G. Tolbert, et al. 1995, Behavior of loggerhead sea turtles on an urban beach. II. Hatchling orientation, Journal of Herpetology, 29(4), 568-576.

[5]. Salmon, M., Witherington B. E., 1995, Artificial lighting and seafinding by loggerhead hatchlings: Evidence for lunar modulation, Copeia 1995(4), 931-938.

[6]. Davis, Scott, Dana Mirick, and Richard Stevens. "Night Shift Work, Light at Night, and Risk of Breast Cancer", Journal of the National Cancer Institute 93:20 2001, 15571562.

[7]. Stevens, Richard. 2005, "Circadian disruption and breast cancer: from melatonin to clock genes, Epidemiology, 16, 710-711.

[8]. Ristinen, Robert, and Jack Kraushaar. Energy and the Environment, 2nd edition. John Wiley, United States, 2006.

[9]. Department of Energy, Energy Information Administration. Electric Power Annual, Washington, D.C.: GPO, 2006.

[10]. Environmental Protection Agency, Office of Transportation and Air Quality. Light-Duty Automotive Technology and fuel Economy Trends: 1975 through 2006, Washington, D.C.: GPO, 2006

[11]. Department of Transportation, Bureau of Transportation Statistics. National Household Travel Survey, Washington, D.C.: GPO, 2001.

[12]. Baumol, William J. "On Taxation and the Control of Externalities," American Economic Review 62: 1972, 307322.

[13]. Baumol, William J., and Wallace E. Oates. "The Use of Standards and Prices for Protection of the Environment," Swedish Journal of Economics 73: 1971, 42-54.

[14]. Wirl, Franz. "Energy Prices and Carbon Taxes under Uncertainty about Global Warming”, Environmental And Resource Economics, 36: 2007, 313-40.

[15]. Picazo-Tadeo, Andres, and Ernest Reig-Martinez. 'Farmers' Cost of environmental Regulation: Reducing the Consumption of Nitrogen in citrus Farming", Economic Modeling, 24: 2007, 312-328.

[16]. Shimshack, Jay P., Michael B. Ward, and Timothy K. M. Beatty. "Mercury Advisories: Information, Education and Fish Consumption", Journal of Environmental Economics and Management, 53: 2007, 158-179.

[17]. Gallaway, Terrel, Reed N. Olsen, and David M. Mitchell, "Value and Beauty in Great Basin National Park's Night Sky" The Midden:The Resource Management Newsletter of Great Basin National Park, 7(2), Fall/Winter 2007, pg. 1.

[18]. Gallaway, Terrel, Reed N. Olsen, and David M. Mitchell, 2008, "The Economics of Global Light Pollution" Ecological Economics, 69(3) pgs. 658-65, 2010.

[19]. Henderson, Vernon, Adam Storeygard, and David Weil. 2012. "Measuring Economic Growth from Outer Space”, American Economic Review, 102, 994-1028 
[20]. Henderson, Vernon, Adam Storeygard, and David Weil. 2011. "A Bright Idea for Measuring Economic Growth”, American Economic Review, 101, 194-199.

[21]. Simpson, Stephanie and Brid Hanna. 2010, "Willingness to pay for a clear night sky: use of the contingent valuation method", Applied Economics Letters, 17, 1095-1103.

[22]. Shultz, W. D., D.S. Brookshire, and M.A. Thayer, 1981. "National Parks and beauty: A test of existence values', presented at the Annual Meeting of the American Economics Association, Washington, D.C.

[23]. Sorg, C. and Loomis J., 1984, "Empirical Estimates of Amenity Forest Values: A Comparison Review" General Technical Report RM 107, Rocky Mountains Forest and Range Experiment Station, USDA Forest Service, Fort Collins, Co.

[24]. Buchli, Loa, Massimo Filippini, and Silvia Banfi, 2003, "Estimating the benefits of low flow alleviation in rivers: the case of the Ticino River," Applied Economics, vol. 35, 585-590.

[25]. Herath, Gamini, and John Kennedy. "Estimating the economic value of Mount Buffalo National Park with the travel cost and contingent valuation models." Tourism Economics 10.1 (2004): 63-78.

[26]. Clarke, Philip M. "Testing the convergent validity of the contingent valuation and travel cost methods in valuing the benefits of health care." Health Economics 11.2 (2002): 117-127.

\section{BIOGRAPHIES}

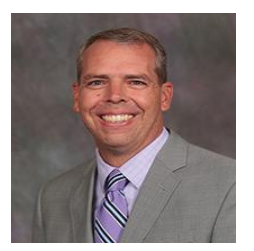

David Mitchell is a professor of economics at Missouri State University. His research interests include election outcomes, light pollution, and the economics of music.

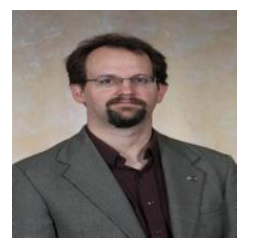

Terrel Gallaway is a professor of economics at Missouri State University. His research interests include light pollution and economic pedagogy.

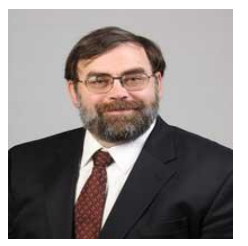

Reed Olsen is a professor of economics at Missouri State University His research interests include healthcare economics, labor economics and light pollution 